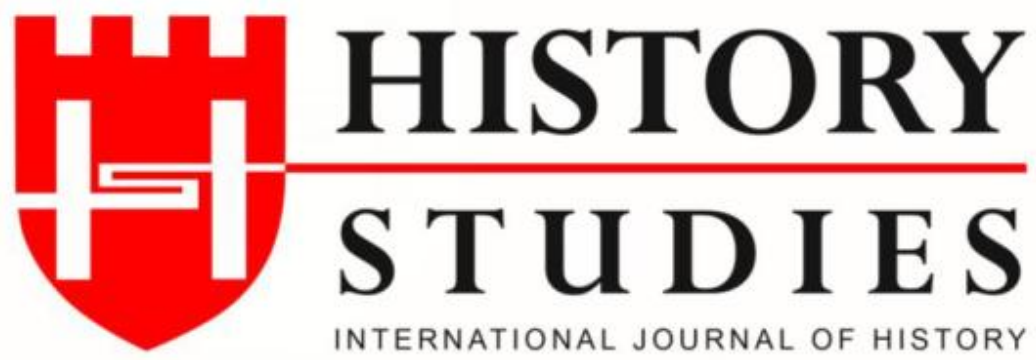

ISSN: 13094173 (Online) 1309 - 4688 (Print)

Volume 8 Issue 4, p. 103-116, December 2016

DOI Number: 10.9737/hist.2017.509

\title{
The Activities of the American Board in Harput with the Observations of Traveller Henry Fanshawe Tozer: The Euphrates (Firat) College
}

Seyyah Henry Fanshawe'in Gözlemleri Doğrultusunda Amerikan Board'un Harput'taki Faaliyetleri: Firat Koleji

\author{
Dr. Ayșegül KUȘ \\ Ondokuz Mayıs Üniversitesi - Samsun
}

\begin{abstract}
Established in Boston in 1810, The American Board of Commisioners of Foreign Missions (ABCFM) opened many schools in the Ottoman lands after 1820. One of these schools opened by the ABCFM was the Euphrates (Firat) College in Harput. This study examines the observations of the British traveller Henry Fanshawe Toze as noted in his book "Turkish Armenia and Eastern Asia Minor" during his visit to Harput and assesses the social, economic and cultural impact of missionaries on the region.
\end{abstract}

Keywords: American Board, Missionaries, Missionary activities, Traveller, Henry Fanshawe Tozer, Harput, Euphrates (Firat) College

Öz: Boston'da 1810 yllinda kurulan American Board of Commissioners for Foreign Missions (ABCFM) adlı protestan misyonerlik teşkilatı 1820 yılından itibaren Osmanlı topraklarında birçok okul açmıştır. Board teşkilatı tarafindan açılan bu okullardan birisi de Harput'ta açılan Fırat Koleji'dir. Bu çalısma, Ingiliz seyyah Henry Fanshawe Tozer'in "Turkish Armenia and Eastern Asia Minor" adlı eserinde, Harput'u ziyareti esnasında kayıt altına aldiğ $\mathrm{l}$ izlenimlerini analiz ederek, misyonerlik faaliyetlerinin bölgenin ekonomik ve kültürel dokusu üzerinde yaratmış olduğu etkiyi tespit etmektedir.

Anahtar Kelimeler: Amerikan Board, Misyonerler, Misyonerlik Faaliyetleri, Seyyah, Henry Fanshawe Tozer, Harput, Firat Koleji

\section{Introduction}

In terms of the government and the law system, the Ottoman Empire was an Islamic state subject to the Sultan-Caliphate and the Sharia. The Ottoman society was multiple-structured in terms of different religions, nations, and the races it consisted of. The tolerance towards the non-Muslims in their religion, language, customs and traditions caused the Empire to be vulnerable to the missionary acitivities carried out by several foreign countries in the region. For instance, from the sixteenth century on, it is seen that some English, French, Sweden, German and American missionaries had come to the Ottoman lands to carry out their religious acitvities under the state guarantee. ${ }^{1}$ Undoubtedly, the meaning of the missionary acquired a different meaning during the course of time. For instance, in its infancy, it meant introducing the Christianity and gaining new believers. However, in the later periods, especially in the seventeenth century as well as meaning sending missionaries to show the true path to the societies in which it is believed that they are misguided and infidel, it also acquired the

${ }^{1}$ Seçil Akgün, "Amerikahı Misyonerlerin Anadolu’ya Bakışları”, Ankara Üniversitesi Osmanlı Tarihi Araştırma ve Uygulama Merkezi Dergisi (OTAM), 3, p.1. 
meaning of sending these missionaries to other societies for political, cultural and economic purposes. $^{2}$ Tozlu states that in the first place the social surrounding, the sources and the dynamics of the missionary schools founded in the Ottoman lands are the minorities; beacuse the minorities were providing many opportunities and in order to reach their ideals and targets these goups were very important as well. ${ }^{3}$ In addition, Kılıç stresses the fact that the missionary activities should not be intrepreted as only spreading the Christianity; because it is a fact that it is not adequate to make a religious propoganda so as to reach the desired target. Therefore, besides the religious propoganda, it is also necessary to carry out some activitivities in the fields such as education and health-care. ${ }^{4}$ One of the first missionary groups having come to Anatolia and carried out some activities were the Catholic Capusens, who arrived in İstanbul in 1220. The second Catholic mssionary group was the Dominicans, who came to İstanbul in the same century. Another Catholic group, the Jesuits, arrived the Ottoman lands in November 1583 with a five-person group. ${ }^{5}$

The second group of the missionaries, who came to the Ottoman lands, were the Protestants. In 1646 when the Republic of England was declared, the new Parliament decided to establish an organisation to spread Christianity and this organisation tried to spread its curent organisation to a much wider field. The political and economic opportunities the Ottoman Empire offered and the desire to set a barrier against the missionary activities of the Catholics caused the Protestant misssionaries to revise their activities in the Ottoman lands in the first half of the nineteenth century and take some effective measures to increase their influence. In the earlier stages, though the activities carried out looked as though they were religious, they actually aimed to create a Protestant community that England could manipulate against France and Russia. Although USA participated in the missionary activities much later compared to other countries, it can be said that it managed to create a desired result for itself. ${ }^{6}$ Gürün states that, the first Protestant missionaries are the members of the "British and Foreign Bible Society" and soon after it was established in 1804, it sarted to send missionaries into the interior parts of the Anatolia. ${ }^{7}$ The American missionaries, who used the British methods, began to come to Anatolia from the year of $1819-1820^{8}$ onward. ${ }^{9}$ American Board missionaries started their activities in İzmir (Symirna) in 1820, and opened their first education schools in Beirut in $1824 .{ }^{10}$ Firstly, they conducted some detailed and in-depth researches to investigate the Ottoman Empire from every aspect and as a result of these researches they thought that it is more appropriate to penetrate into the Ottoman edecation and the health system. Actually, the first relations between the United States of America and the Ottoman Empire had already

\footnotetext{
${ }^{2}$ Metin Hülagü, “Osmanlı'dan Cumhuriyet'e Misyoner, Ermeni, Terör ve Amerika Dörtgeninde Türkiye” Erciyes Üniversitesi Sosyal Bilimler Enstitü Dergisi, Kayseri 2001, p.1.

${ }^{3}$ Necmettin Tozlu, “Osmanlı Devleti'nde Ermeni Eğitim Kurumları ve Faaliyetleri”, Yeni Türkiye, S.60, 2014, p.3.

${ }^{4}$ Orhan Kilıç, "Kendi Yazdıkları Işı̆̆ında Amerikan Misyonerlerin Harput’taki Faaliyetleri”, Journal of Islamic Research, 20 (4), 2007, p.477.

${ }^{5}$ Nurettin Polvan, Türkiye'de Yabancı Öğretim, C. I, İstanbul: MEB Yayınları, 1952, p.66, 69-70.

${ }^{6}$ Hülagü, "Osmanlı'dan Cumhuriyet'e Misyoner...", p.2.

${ }^{7}$ Kamuran Gürün, Ermeni Dosyast, Ankara: TTK, 1983, p.40.

${ }^{8}$ The year of 1820 is important in terms of the development of the missionary movement in America. Namely, the Protestants gathered under the organisation called American Board of Commissioners for Foreign Missions so as to make the Protestant sect more widespread in the other parts of the world soon after the "Awakening" Protestant movement. The main purpose of ABCFM was to guide the missionaries to spread the Christianity mainly to native Americans in the United States of America, in the American continent and the world, see. Akgün, "Amerikalı Misyonerlerin Anadolu'ya Bakışları", p.2.

${ }^{9}$ Erdal Açıses, Amerikalıların Harput'taki Misyonerlik Faaliyetleri, Ankara: TTK, 2003, p.35.

${ }^{10}$ Gülbadi Alan, "Amerikan Board Okullarında Yürütülen Misyonerlik Faaliyetleri”, Journal of Islamic Research, 20(4), 2007, p.465.
} 
started, but after the "Peace and the Commerce Treaty" was signed in 1830, these relaitons took more official and legal form. ${ }^{11}$ For instance, this treaty became an effective factor for the American missionaries to establish a station in İstanbul. Besides developing good relations, it is asserted that the reason why American missionaries started to act freely resulted from the great interest of the Ottoman authorities in the American weapons and the war ships. ${ }^{12}$ Following this treaty, the missionaries of American Board organised three mission zones in the Ottoman lands in 1835. The first of these missions is the Syria-Palestine Mission, the important stations of which are Beirut, Sayda (Sidon), Abeih, and Trablus (Tripoli). The activities of this mission were carried out by the American Board until 1870 and in the same year it was transferred to another Protestant missionary organisation The Board of Foerign Missions of the Presbyterian Church. The second one is the Istanbul Mission, which was organised with a single station by the mssionary Goodell in 1831. The third mission is the Asia Minor Mission, which covered İzmir, Bursa, Trabzon, and Chios Island. However, the Istanbul Mission and the Asia Minor Mission merged in 1839 and it was called as the Turkey Mission. ${ }^{13}$

One of the most outstanding activities of the American Protestant misisonaries, who flooded the Ottoman lands in 1820 took place through the schools which are in the center of the cultural activities and which would be the pioneer of the economic share and would be also complemantary in the future; because it was believed that it was possible to get closer to the native people and persuade them into their own faiths and manipulate their lives only through education and the schools. Since the education leads and shapes the life, any religion which aims to give message to an individual or a community regards the education as the most effective means. It is understood that the missionaries soon became aware of this fact. ${ }^{14}$ As a result of the experiences the American missionaries gained in the early years, they clearly undestood that the best method that could ease their work in the Ottoman lands would be education. They started to carry out activities towards the conversions beforehand. They were aware of the fact that they needed to adopt some effective means such as education so as to draw the attention of the native people so that they could understand their preachings and they could help them with their work. More importantly, even though the Ottoman Empire gave special importance to the education during the Reform periods, it took a lot of time and required great efforts to realize; because there was such a great need for the education that even some non-Muslim clerics were illeterate. Moreover, the religious rituels were done in the language (the old Armenian) that the people could not understand. ${ }^{15}$ Similarly, Danacioğlu points to the fact that when they preached the missionaries could reach too many people

\footnotetext{
${ }^{11}$ Açıkses, "Türk-Amerikan Münasebetlerinin Değerlendirilmesi”, Türkler, C.13, Ankara: Yeni Türkiye Yayınları, 2002 , p. 542.

${ }_{12}^{12}$ Uygur Kocabaşoğlu, Kendi Belgeleriyle Anadolu'daki Amerika, İstanbul: Arda Yaymevi 1989, p.34.

${ }^{13}$ Alan, Osmanlı Imparatorluğu'nda Amerikan Protestan Okullarl, Ankara: TTK, 2015, p.6-7. 1860 is the year when the American Board gave the last form to its organisational structure in the Ottoman lands. Namely, as a result of the decisions taken at the annual meeting of the Board in Harput, the activities carried out in Anatolia were organised within the fgramework of a three-mission zone. In line with this organisational structure, the region where the line is drawn from Trabzon to Mersin left in the west was called the Western Türkiye Mission, the stations of which are İstanbul, izmir, Bursa izmit, Merzifon, Kayseri, Sivas and Trabzon after 1885. The region form the southern of Sivas to Mersin and Halep (Aleppo) was called Central Türkiye Mission, the stations of Which are Maraş, Adana, Antep, and Haçin and the region, the stations of which are Harput, Erzurum, Van, Bitlis and Mardin was called the Eastern Türkiye Mission, The last change in the organisation was made in 1871 and the land in the west of İstanbul was called European Türkiye Mission see Alan, Amerikan Protestan Okullarl, p.7-8.

${ }^{14}$ Alan, Amerikan Board'un Merzifon'daki Faaliyetleri ve Anadolu Koleji, Ankara: TTK, 2008, p.3-4.

${ }^{15}$ F. A. Stone, Academies for Anatolia, Boston: University of Connecticut, 1984, p.28; Kocabaşoğlu, Anadolu'daki Amerika, p.46.
} 
through the schools. ${ }^{16}$ In this context, it is seen that soon after the İstanbul station was established four schools were opened in order to give basic education to the Greeks. The first schools opened were guite simple and even the education place, mission center and the place where the missionaries lived were the same building in most cases. Depending on some social and political and economic developments the number of these schools increased rapidly throughout the nineteenth century. Of course, these schools were not only American Board schools. There had been an increase in the number of the schools opened by other countries as well. However, the American Board schools form an exception in terms of the effective educational activities carried out and the number of the schools it opened in the Ottoman lands. ${ }^{17}$ Therefore, the American missionaries made the greatest contribution to the development of the Protestant missionary rather than the British missionary organisations; because the American missionary organisations became more effective in the political and cultural fields and they became a dominant element in the determination of the diplomatic relations. $^{18}$

To Alan, the increase in the number of the schools in the nineteenth century is mostly related to westernisation trend in the Ottoman administration. Moreover, Alan gives three major turning points for the activities of the westernisation: Tanzimat Edict in 1839, the Islahat Edict in 1856 and the I. Meşrutiyet declared in 1876. As a result of these developments and the rapid increase in the westernisation the American Board missionaries opened more schools day by day. Therefore, it is seen that the number of these schools increased especially after the 1870s. ${ }^{19}$ Among these important schools opened by the Board are the Robert College in İstanbul, The Anatolian College in Merzifon, the Frrat College in Harput, The İstanbul American Girls' College, the American College in Van, the International American College in İzmir, the Central Turkey College and the Syrian Protestant College. ${ }^{20}$ In these schools along with English, however, the study of the modern Armenian was also emphasized at the Bebek Seminary, There was always capable native teacher of Armenian language and literature on the faculty. For instance, Cyrus Hamlin explains the purpose of the bebek Seminary as "One's native language, his mother tongue, must be his chief instrument of thought and expression, our course gave a great impulse to the cultivation of the Armenian language. We found it clay and iron and left it gold". 21

The American Board schools also drew the attention of some foreign travellers when they visited the Ottoman lands. One of these travellers is Henry Fanshawe Tozer ${ }^{22}$, who came to Harput in 1879. During his visit to Harput and the western Tigris, he made a detailed and an in-depth observation of the College founded by the American Board ranging from its students to the course of study pursued, the Boys' school, the Girls' School and the overall influence of the American missions in the region. Therefore, the purpose of this study is to benefit from the accounts of Tozer with regard to the activities of the American Board in Harput and make

\footnotetext{
${ }^{16}$ Esra Danacıŏlu, “Osmanlı İmparatorluğu'nda Amerikan Board Okulları ve Ermeniler”, Dokuz Eylül Üniversitesi Atatürk İlkeleri ve İnkılap Tarihi Enstitüsü Dergisi, C.3, S.9-10, 1999-2000, p.134.

${ }^{17}$ Alan, "Amerikan Board Okullarmda...", p.467.

${ }^{18}$ Mithat Aydm, "Amerikan Protestan Misyonerlerinin Ermeniler Arasmdaki Faaliyetleri ve Bunun OsmanlAmerikan İlişkilerine Etkisi”, OTAM, S. 20, Ankara, p.81.

${ }^{19}$ Alan, "Amerikan Board Okullarinda...", p.467-468.

${ }^{20}$ George Wasburn, Fifty Years in Constantinople, Boston: Riverside Press, 1909, p.54-55.

${ }^{21}$ Cyrus Hamlin, My life and Times, Boston: The Pilgrim Press, 1893, p.250.

${ }^{22}$ Tozer is an English author, academician and the traveller. Actually, he planned to visit Anatolia in 1874. However, he had to postpone his journey, due to the famine in Anatolia, and the 1877-78 Ottoman-Russian War. During his visit he wrote down his observations and it was published in 1881 titled as "Turkish Armenia and Eastern Asia Minor", see. Henry Fanshawe Tozer, Turkish Armenia and Eastern Asia Minor, London 1881, p.viii.
} 
some contributions to understanding and evaluating the importance of the acitivities up on the socio-cultural history of the region much better from the perspective of a foreign traveller.

\section{The Euphrates College (Furat Koleji) in Harput}

After giving a brief historical account of Harput, Tozer makes a visit to Frrat (Euphrates College). In his acconts he calls it as "Armenia College", for it is intended for the whole country. First of all, he mentions that this school was founded three years before with the great efforts of Mr. Wheeler, who collected 12,000 liras in America for the purpose of diffusing Christian civilisation and preparing intelligent Christian leaders in all departments. ${ }^{23}$ Although Tozer does not give the exact date for the foundation of the school, it can be inferred from the information in the preface of his book ${ }^{24}$ that it was opened in 1876 because he states that he visited Turkey in 1879. Actually, since the American Board felt responsible to respond to the demands of the native people in the later years the authorities of the Board did their best in order that these schools could be established..$^{25}$ As there had been the same demand for such schools in Harput as well, the American missionaries had started to think over it since 1870. In 1870 , there were nearly 100 schools and churches in the neighbourhood. As a result of these developments, the necessary preparations started. ${ }^{26}$ Tozer states that the money collected for the college was 12,000 liras, while Stone mentions that Crosby H. Wheeler managed to collect 140,000 dollars as a result of his efforts when he was on a home leave in America. ${ }^{27}$

When 40,000 dollar native contribution was added to it by local Armenian contributors,

HISTORY STUDIES

\footnotetext{
${ }^{23}$ Tozer, Turkish Armenia, p.226.

${ }^{24}$ Tozer, Turkish Armenia, p.vii.

${ }^{25}$ Açıkses, Harputtaki Misyonerlik Faaliyetleri, p.94.

${ }^{26}$ Kocabaşoğlu, Anadolu'daki Amerika, p.189.

${ }^{27}$ Stone, Academies for Anatolia, p. 168.

${ }^{28}$ Stone, Academies for Anatolia, p. 168.

${ }^{29}$ There have been different opinions regarding the establishment date of the College. For example, Şimşir mentions that it was established in 1859 when the Theological School was opened, see. Bilal Şimşir, "Ermeni Propagandasının Amerika Boyutu Üzerine" Tarih Boyunca Türklerin Ermeni Toplumu İle İlişkileri Sempozyumu, 8 12 Ekim 1984, Ankara 1985, p.95. Sunguroğlu in his book mentions that the Mission in Harput was able to establish a big school in 1876 and Crosby H. Wheeler was the director of the school and al Dr Barnum also continued to work in Harput as the assistant of Mr. Wheeler, see. İ. Sunguroğlu, Harput Yollarında, C.1, İstanbul 1959, p.85. On the other hand, Alan states that the Euphrates College (Frrat Koleji) in Harput (Mamuratülaziz) was established in an Armenian quarter called "Şehroz" in 1857 in order to give education both to girls and boys at the primary, secondary and high school levels. To her, its administration and its belonging had not been chaneged since the date of its establishment, see. Alan, Amerikan Protestan Okullarl, p.226-227; Stone states that despite the extensive education network, the schooling in Harput did not give the students to have an access to the higher education in Harput and that a college is needed to supply students for the higher education. Thus, the Rev. Croisby H. Wheeler more than 140,000 dollars for it when he was on a home leave in the United States and 40,000 dolar was donated by the local Armenian contributors. When the Trustees of Armenia College Funds was incorporated in Massachusetts on May 13, 1878 nearly 181,000 dollars was available to pay for the new venture, see. Stone, Academies for Anatolia, p.168. Sezer states that the Armenian College, which the Ottoman State called Frrat College was established in Harput in 1878 and it followed the educational program which aims to raise Protestant cleric and teach the Armenians their languages, history, literature and nationality, see Ayten Sezer, "Osmanll'dan Cumhuriyet'e; Misyonerlerin Türkiye'deki Eğitim ve Öğretim Faaliyetleri”, Hacettepe Üniversitesi Edebiyat Fakültesi Dergisi, October 1999, p.175.

${ }^{30}$ M. A. Melcon, " The Growth and Influence and Needs of Euphrates", The Missionary Herald, Vol.99, No. 1, January 1903, Boston 1903, p.14.
} 
January 1888 and it was called "The Euphrates College" owing to the river flowing very close to it. ${ }^{31}$

Tozer goes on to give more details regarding the school. To him, the school is in a higher position than the primary schools that are in the other American stations and in Harput these are maintained by the native Protestant community. He states that the College has an independent status and also it is divided into two: the normal school and the higher school or college proper. ${ }^{32}$ As Tozer points out, the education which was divided into two was subject to a different categorization from its orphanage to the Theological School, the kindergarden and from the primary, secondary and the high school to the higher level of the college. ${ }^{33}$ Tozer also mentions that they accept all who are willing to pay the usual fees of the school. ${ }^{34}$ Rightly, wheras the Theological School was free of charge the students were obliged to pay fees for the other schools The fee was changing in accordance with the level of the education given. For example, at the higher level of of the Euphrates College the students used to pay for the lodging as well as the fee. Whereas the fee in the first grades was 1 dollar, the fee increased to 6,40 dollars in accordance with the grades in the College. ${ }^{35}$ In addition, it is pointed out that the payment for board and lodging and also for those in the normal school was 5 liras, but the payment for the instruction is somewhat less. ${ }^{36}$

\subsection{The Normal School}

Tozer first visits the normal school and gives some information regarding its physical features, the teachers working there, the students and the curriculum. First of all, he mentions that it had a large and airy room and it had 80 scholars in the school, but since they visited the school on the first day of the term not all of them were present at school, especially the ones from the distant places such as Diyarbakır had not come yet. Moreover, the lessons had not started, either. He goes on to give some accounts of the subjects taught at the school. Besides the study of the Bible, the subjects taught at school are elementary English and Turkish, arithmetic, algebra, history. To him, the students came from all parts of the country from Egin on the Firat river towards the north to Diyarbakir and Bitlis in the south and the east and they were selected from the local schools that had connection with the missions. ${ }^{37}$ From the recounts of Tozer, It is clearly seen that the students attending the college come from the local schools which are connected with the missons.

\subsection{The College Proper (the Higher School)}

Tozer states that the number of the students attending the college proper is 33 and the ones who cannot pay the amount mentioned above are financially supported. He even gives the account of his donation for the school in order that one of the students who cannot pay can continue his education. ${ }^{38}$ In the following lines, the traveller goes on to give some information about the students at the higher school at the College. First of all, he says that some of the pupils are Jacobites ${ }^{39}$ who became Protestants, but the most of them are Armenians. Moreover,

\footnotetext{
${ }^{31}$ Melcon, “ The Growth and Influence...", p.14.

${ }^{32}$ Tozer, Turkish Armenia, p.226-227.

${ }^{33}$ Stone, Academies for Anatolia, p.157.

${ }^{34}$ Tozer, Turkish Armenia, p.227.

${ }^{35}$ Kocabaşoğlu, Anadolu'daki Amerika, p.227.

${ }^{36}$ Tozer, Turkish Armenia, p.227.

${ }^{37}$ Tozer, Turkish Armenia, p.227.

${ }^{38}$ Tozer, Turkish Armenia, p.227.-228.

${ }^{39}$ The Assyrian (Syriac) Orthodox Christians or Suryani, sometimes called Jacobite, lived chiefly in Anatolia southeast. The historic name for this region is Tur Abidin (Believers' Mountain). The same area was also called
} 
he stresses the fact that the students have different natioanalities and speak different languages such as Turkish, Kurdish and Armenian and none of these languages are represented in his university. In addition, he goes on to give some accounts about a Kurdish pupil at the high school. From his accounts, it is understood that he finds him very interesting and so anxious to learn that he coud not be kept from coming to the college. To Tozer, he generally represents the Kurdish physiognomny different from the other pupils. Tozer also states that the dialect of Kurdish spoken in the region between the two main branches of the Tigris differs so much from the ordinary language that the other Kurds do not understand it. ${ }^{40}$ Moreover, during the Ottoman Empire, however, Kurdish identity, as has been exlained by Tozer, was actually complicated by the religious diversity within this group. Perhaps, \%30 were not Sunni Muslims, the official Ottoman faith, but Alevi or Shiite. Besides these, the other Kurds practiced some syncretistic beliefs that had come down from the ancient Iranian religions, including Zoroastrianism. There were also major differences in dialects of the spoken Kurdish, which is an Indo-European language wheras Turkish is Ural-Altaic. Owing to these complexities, the educators working for the ABCFM had to take such things into consideration while preparing the educational programs. ${ }^{41}$ As can be seen, even though Armenians, the main body of the non-Muslim population, received the major interest of the ABCFM and its Eastern Turkey Mission in the region, It is undestood that they also focused their attention on the other groups such as Arabic and Kurdish speakers in order to bring enlightenment to them. For example, out of 81 men who had attended the Harpoot Theological School before 1867, nine of them spoke Arabic and the mother tongue of the six was Kurdish. ${ }^{42}$ During his visit to the classes he also noticed that when the students were requested to recite the Lord's Prayer in their own tongue, the Armenians could hardly understand their Church service in the old tongue. ${ }^{43}$ As has been pointed out by Tozer, since the old Armenian was not known among the Armenians, the Holy Book was translated into modern Armenian. In 1821 the Bible was traslated from the Old Armenian into modern Armenian and the English Society also tranlated it into daily language. ${ }^{44}$ As can be seen, the words of Hamlin aforementioned highlight the purpse of these schools opened in the Ottoman lands. Tozer is also given information about the position of the College it holds to the Muslims by Mr. Wheeler, the director of the College. He finds out that the College is eager to accept the Muslim students and very few of the Turks are willing to send thier sons to the College, but they do not dare to do because of the fear of the ridicule or more probably they are afraid of their co-religionists. ${ }^{45}$ As has been explained by Tozer, Muslims do not send their sons to schools opened by the missionaries. ${ }^{46}$ Mr. Wheeler explains it as "at all times, however, they look upon it with suspicion, because they are aware that education is likely to undermine their supremacy." 47 However, to Tozer, the statement made by Mr. Wheeler as "they fear our pen" actually means that the former opposition and abuses do not take place because such sort of events are immediately reported to the head-

Jabal Tur (Jabal is Arabic for mountain), or in Trkish Tur Dag. Actually, Tur is the Syriac word for mountain. Syriac is orginal tongue of this millet. The nearest major city is Diyarbekir. The partly Christian town of Mardin was on a ridge overlooking the Syrian plain on the western side of Tur Abidin, see. Stone, Academies for Anatolia, p.128.

${ }^{40}$ Tozer, Turkish Armenia, p.228-229.

${ }^{41}$ Stone, Academies for Anatolia, p.129.

${ }^{42}$ Stone, Academies for Anatolia, p. 123

${ }^{43}$ Tozer, Turkish Armenia, p. 228.

${ }^{44}$ Ayhan Öztürk, "Amerikan Board'un Kuruluşu ve Teşkilatlanması ve Osmanlı Devletinde Kurduğu Misyonlar”, Erciyes Üniversitesi Sosyal Bilimler Enstitü Dergisi, Kayseri 2007/2 S. 23, s. 63-74.

${ }^{45}$ Tozer, Turkish Armenia, p.230.

${ }^{46}$ Melcon, "The Growth Influence and...", p.15.

${ }^{47}$ Tozer, Turkish Armenia, p.230. 
quarters. As far as the accounts of Tozer permit us to discern, the role and influence of the missionairies they had seems to have increased after the 1877-78 Ottoman-War due to some political developments in favour of them. Moreover, Tozer points out that he was told that Mr. Wheeler was in touch with the Consul Layard and he asked Mr. Wheeler to provide information about what was happening. In addition, he exemplifies this influence as "a pasha due to his ill-will towards the missionaries received a sharp reprimand from Constantinople."

In the following lines, Tozer gives details with regard to the subjects taught at the Higher School. He mentions that the course of studies pursued is very wide and it consists of the Greek, French and Persian languages, law, natural, mental and moral philosophy, geometry, astronomy and physiology, theology, music and drawing. In addition, he states that they observed that the students could read English well. ${ }^{49}$ Although the instruction at the College is Armenian, the other languages were also taught at higher grades of the College. In addition, though it was objected before, English became the second language after Armenian compared to other languages taught. ${ }^{50}$ Kocabaşoğlu states that at the higher grades of the Euphrates (Firat) College, a high-level English was taught in order to follow the American course books and to understand the classes of the missionaries who do not know the native languages. ${ }^{51}$ Moreover, as in most of the Board schools in the Ottoman Empire, the instruction of the education was mainly given through a foregin language because the purpose of the missionaries is to try hard for English to take place of French, which was the common foreign language in the Ottoman Empire. ${ }^{52}$ For example, in an American Consular report in 1909, it is stated that the English is shaped with the great interest of the missionaries in schools, colleges and orphanages in this country. ${ }^{53}$ As can be seen, the curriculum followed at the College is actually very comprehensive and it is aimed to educate and equip the pupils with several skills and prepare them for their future life well.

In the following lines, Tozer also makes a detailed and in-depth evaluation of the system of the instruction for the reader. First of all, he states that although he found the system admirable, he had an objection to it saying that it was too detailed in terms of its purpose. In his recounts, he mentions that Mr. Wheeler did not agree with him, for he thought that the pupils who were well-educated in that manner had more enthusiasm for civilisation and when they went back to their homes, they played an important role in their communities. In addition, the influence of this education displays itself in the daily life such as cleanliness in the houses, the prints hung about the walls or the evidences of the interest in something beyond everyday concerns. Besides these, they have the positions of usefulness as teachers in local schools or pastors of Protestant congregations, etc. ${ }^{54}$ Actually, these statements reflect the real purpose and the function of the Board schools in the Ottoman lands. Similarly, Alan also states that in the final stage the missionaries opened colleges to advance the education one step further in order that the students could increase their vocational skills, gain more experience and develop self-confidence. To Alan, though the number of these schools is fewer when compared to other

\footnotetext{
${ }^{48}$ Tozer, Turkish Armenia, p. 230.

${ }^{49}$ Tozer, Turkish Armenia, p. 229.

${ }^{50}$ Açıkses, Harputtaki Misyonerlik Faaliyetleri, p.149.

${ }^{51}$ Kocabaşoğlu, Anadolu'daki Amerika, p.190.

${ }^{52}$ Emine Dingeç, "Amerikan Misyoner Okullarının Ermeni Ayrılıçı Hareketindeki Etkileri Üzerine Bir Değerlendirme", Yeni Türkiye, S.60, 2014, p.3.

${ }^{53}$ Dingeç, "Amerikan Misyoner Okullarının...", p.3.

${ }^{54}$ Tozer, Turkish Armenia, p.229.
} 
schools, they could manage to play a crucial role both in educational and social life through their graduates from the school. ${ }^{55}$

\subsection{The Girls' School}

The early conditions of education in Harput in the 1850s were not in good state. For instance, Barnum explained these early conditions as being in the primitive state and he stressed the fact that the female education would not be possible if there was no effort, persistance and the persuasion of some of the missionary ladies. ${ }^{56}$ There was no school for women in Harput. Melcon, a lad of sixteen and who taught in the local school, brought his sister and an Armenian girl into class where they studied with the boys. Then a second school in Harput and another one in the nearby town of Mezere (Elazığ) started to give education by Dunmore, The school in Mezere began to be taught by Krikor Tamzarian, who later became the Prostestant pastor at Itchme (İçme). ${ }^{57}$ A few years later in May 1861, the Northern Armenian Mission, a predecessor of the Eastern Turkey Mission gathered in Harput and the missionaries decided that a Female Seminary should be opened there. The main objectives of the institution are as follows:

1. First, many of the Theolgocial students' wives were illiterate and they needed preparations if they were to assist their husbands in their pastorates. A single room on the housetop had already been set aside for the women and an elderly priest was struggling there to teach them reading and writing.

2. Second, no unmarried man who graduated from the Theological Seminary could be ordained until the wed. The fifteen unmarried boarding school girls at the Harpoot Female Seminary, after it was opened, comprised a source of well-educated, pious potential spouses for the aspirant pastors.

3. Third, teachers were always going to be needed to staff the schools that went along with the Protestant chapels. The new Female Seminary was designed to prepare them. ${ }^{58}$

First of all, Tozer recounts that he visited the the girls' school the following morning and that it was designed to have the same position for women just as the college did for men. $\mathrm{He}$ goes on to say that the students at the school are boarders and come from the different parts of the country and the number of the students is nearly 35 like the number of the boys. The school administration provided many facilities so that they could persuade the parents to send their daughter to the school. For instance, the girls paid only half as much for this tuition as their brothers. Even though the boarding fee was 22 dollars a year, some had to be given a discount. Besides these, textbooks were rented to the girls wheras the boys had to purchase theirs. It is clear that school costs are arranged to make the Euphrates College as attractive as possible to the parents of the girls. ${ }^{59}$ However, to him, the number of the students decreased because of the fact that partially there was a widespread poverty and partially there was was not sufficient appreciation for the education of the women. In the following lines, Tozer focuses on the importance of the education of the women saying that the future of the new generations absolutely depends upon the mothers of the families and he gives the example of the girls' school established by Dr. Hill pointing out that it played an important role in the Greek

\footnotetext{
${ }^{55}$ Alan, “Amerikan Board Okullarmda...", p.466.

${ }^{56}$ Herman N. Barnum, "Fourty Years in Harpoot, Eastern Turkey", The Missionary Herald 95(10), October 1899, p. 402 .

${ }^{57}$ Melcon, "The Growth and Influence and...", p.14.

${ }^{58}$ Stone, Academies for Anatolia, p. 120.

${ }^{59}$ Stone, Academies for Anatolia, p.171-172. Crosby H. Wheeler, "Euphrates College, Harpoot, Turkey" The Missionary Herald, Vol.84. No.3, March 1888, Boston 1888, p.137.
} 
society. ${ }^{60}$ From the explanations of Tozer, it is seen that the missionaries also gives a special importance to the education of women. As has been mentioned by Tozer, the girls having graduated from the American Board schools trasferred all they had learned from the schools to their families. During their education in the schools, they were specially trained so that they could be good housewives, run a house and most importantly they could be good mothers for their children. Thus, the girls took their place in the society to be a good and educated candidate for the spouses of the males who graduated from the Board schools. As a result of this, the education given to girls was not only designed to educate an individiual in the society but to educate an individual to permeate the whole society. This policy adopted by the American Board produced effective results with the educational activities carried out among the girls. ${ }^{61} \mathrm{He}$ also mentions the subjects taught at the school as arithmetic, English, Turkish, the Bible and other more advanced classes. ${ }^{62}$ Then he provides some information about the girls in the school, Tozer recounts that most of the pupils were good-looking and the way they dressed is very picturesque. He goes on to say that they sang some hymns in English and Armenian and also they did calisthenics consisting of gesticulations with the arms up and down and backwards and forwards accompanied by clapping of hands and moving in and out form side to side. ${ }^{63}$ From his recounts, it is understood that he derived pleasure from the educational atmosphere in the classes. Lastly, he says that the school was conducted by two unmarried American ladies. In addition, Stone states that among the other teachers, both Mrs. Wheeler and her daughter, Emily completed their education in Massachusetts. For instance, Emily taught at the Harput school for sixteen years. Mrs. Wheeler taught English literature to the girls while the physical geography was taught by Miss. Barnum. Singing, as has been recounted by Tozer, was instructed by Miss Daniels and Miss Wheeler. The girls were also lectured on pedagogy by Miss Daniels. ${ }^{64}$ Even though Tozer had some objections to the system conducted and adopted by the missionaries, he states that the schools need to be received great praise in that the usefullness of the schools is recognised by the native people. ${ }^{65}$

\subsection{The Evaluation of the American Mission in Harput}

In his book, Tozer also makes some evaluations with regard to the mission to which these schools belonged and the represantatives of the schools whom he met with in Kayseri and Sivas and whom he would meet in Erzurum and Van. However, He points out that the mssion in Harput is the most important one and its influence extends over numerous villages which reach for six or seven days' journey in the south and also three or four in the north. ${ }^{66}$ Similarly, Stone firmly states that Harput, nearly 800 miles east of Constantinaople became the fulcrum for the American Board education in eastern Anatolia just as Smyrna (İzmir) and Marsovan (Merzifon) had in the western Turkey Mission and Aintab (Antep) and Marash (Maraş) in the Central Turkey Mission. ${ }^{67}$ Moreover, in the report sent to Boston by George W. Dunmore, it is also pointed out that Harput was the richest plain he had ever seen and it was the promising place with regard to the missionary activities to be carried out. ${ }^{68}$ Then, Tozer puts forward

\footnotetext{
${ }^{60}$ Tozer, Turkish Armenia, p.234.

${ }^{61}$ Cenk Demir, "Amerikan Board Belgelerine Göre Talas Amerikan Kız ve Erkek Kolejleri”, Turkish Studies, Vol. 7/4, Fall 2012, p.1410.

${ }^{62}$ Tozer, Turkish Armenia, p. 235.

${ }^{63}$ Tozer, Turkish Armenia, p.235.

${ }^{64}$ Stone, Academies for Anatolia, p. 121.

${ }^{65}$ Tozer, Turkish Armenia, p. 237.

${ }^{66}$ Tozer, Turkish Armenia, p.235.

${ }^{67}$ Stone, Academies for Anatolia, p.116.

${ }^{68}$ Şimşir, "Ermeni Propagandasının Amerikan Boyutu Üzerine, p.95.
} 
some of his objections to the missinonaries saying that the they would be the first to say that their major focus is on the religion not on the education. In addition, he states that their aim as religious teachers does not seem to reform the existing Armenian Church, but to establish Protestant communities consisting of the members of that Church. Tozer firmly states that he does not approve of this, for he strongly advovates the idea of the national churches, especially in the east in which the notion of nationality is the strongest motive. He also objects to the idea of one communion interfering in the affairs of another communion. ${ }^{69}$ Rightly, he refers to the fact that the missionaries in the east deviated from their real objective and that they were permeating the whole society through their Evangelical doctrines and were working hard to create a seperate Protestant community. However, to him, "much more would be gained for Christianity by gathering up the fragments that remain" because a large number of people would adhere to their own Church, which was connected with their national history. ${ }^{70}$ In that sense, he gives the example of the system followed by Dr. Hill, who promoted the religious education without interfering with the Church by leaving it to the enlightenment to promote reformation. ${ }^{71}$ Furthermore, he remarks that he disapproves of any interference with these people and that though the way they advance may not be approved by the people in the west, interference will only bring much confusion, for their system is very rooted and any agency might hamper them. ${ }^{72}$ Then, Tozer adds that he does not expect everyone to agree with his own view, especially the ones who belong to the Congregationalist (Independent Body), who think that they accomplished a great success since they managed to establish their own communities so widely throughout the country. ${ }^{73}$ From the statements of Tozer, it is clearly understood that the aim of the missionaries is not so innocent as it does seem. On the contrary, it is quite possible to state that they paved the way for separation and confusion not only among the Armenians but also between the Armenians and the Turkish people by interfering with the Christian local peoples' Church and imposing their Evangelical doctrines under the mask of religion, education, health and aid. The statements of Tozer as "it might have been foreseen from the first that a rupture would be the consequence. The immediate cause of seperation, however, was the persecution of the converts by the Armenian Patriarch." ${ }^{74}$ rightly points to the possible danger and threat to which the Ottoman society would be exposed in the following years. Actually he makes remarks on the possible and dangerous consequences of the method adopted by the missionaries so that they could reach their aims in the Ottoman lands. Therefore, his statements and his evaluations about the system adopted by the missionaries in Harput are very crucial to be able to undestand and evaluate the real role of the missionaries and their activities they exercised in the Ottoman lands in the nineteenth century.

\section{Conclusion}

Firstly, it should be stated that the special location of Harput in the eastern Anatolia must have caused the missionaries to choose it as the mission base and the central spot and increase their activities in the region. In this sense, the missionaries came to Harput and launched their educational activities in order that they could reach large numbers of people living in Harput and the villages in the vicinity of Harput, especially in the second half of the nineteenth century. It is seen that Tozer visited the region in the period when the educational activities of the Board were at its peak (soon after the Ottoman-Russian War in 1877-78). Tozer gives

\footnotetext{
${ }^{69}$ Tozer, Turkish Armenia, p.235-236.

${ }^{70}$ Tozer, Turkish Armenia, p. 236.

${ }^{71}$ Tozer, Turkish Armenia, p. 237.

${ }^{72}$ Tozer, Turkish Armenia, p.238.

${ }^{73}$ Tozer, Turkish Armenia, p. 237.

${ }^{74}$ Tozer, Turkish Armenia, p. 236.
} 
detailed information with regard to the College, but he does not mention any specific date related to its foundation. As far as his accounts allow us to discern, like the other schools in the Ottoman lands most of the students in the Frat College are Armenians and there has been a small number of Kurdish students, but there has been no Turkish student at the College during his visit in Harput. From the accounts of Tozer it is clear that the American Board founded the College to provide higher education both for boys and girls. It is also very striking that the Board gave special importance to the education of girls for the purpose of the permeating and transforming the society through the education of women. Another point to be stressed is that the number of the students accepted into schools is only limited to 35 both for girls and boys. Thus, it is obvious that the students are selected with special care so that the missionaries can reach their goals. Moreover, Tozer considers the curriculum followed by the school administration too elaborate for its purpose. Although the subjects taught at the school are varied and complicated, it is quite possible to say that the school administration consciously designs such an eloborate curriculum in order to equip the students (both girls and boys) with some necassary skills that are urgently needed in the Ottoman society so that they can permeate into the society and transform it more easily in the way they imagine. Thus, the education the students are given seem to be more beyond the educational facilities provided by the Ottoman Empire.

It should also be borne in mind that though Tozer is Protestant, he appears to have made some objective observations and analysis regarding the activities of the American Board in Harput. Especially, it is highly important that he make some in-depth analysis related to the interference of the Protestant misssinaries in the national Church of the Armenians and he strongly points to the possible dangers of such an interference stating that it might lead to seperation and some confusion among the Armenians rather than promote the reformation in the Armenian Church itself. Therefore, it should be pointed out that Tozer puts forward his objections to the system followed by the missionaries and warns that though the benefit of the schools are admired and recognised by the native people, the misssionaries inflicting the Evangelical doctrines in the schools naturally lead to some antagonism among them. Besides these, he remarks that on the surface the missionaries claim that they do not take in part in the politics, they are indirectly in communication with the European consuls. In this sense, what Tozer remarks on the schools and the policy followed by the missionaries help us to understand the real role and purpose of the Board schools and more importantly cast light upon the future social and political developments in the following years. Therefore, the accounts and the evaluations of Tozer appear to be more objective when compared to other western travellers and researchers, who generally write down their impessions under the influence of the religion and the culture to which they belong to.

\section{Bibliography}

AKGÜN, Seçil, “Amerikalı Misyonerlerin Anadolu'ya Bakışları”, Ankara Üniversitesi Osmanlı Tarihi Araştırma ve Uygulama Merkezi Dergisi (OTAM), Issue 3, 1992: pg.1-16.

AÇIKSES, Erdal, “Türk-Amerikan Münasebetlerinin Değerlendirilmesi”, Türkler, Volume 13, Ankara: Yeni Türkiye Yayınları, 2002: pg. 542-557. , Amerikalıların Harput'taki Misyonerlik Faaliyetleri, Ankara: TTK, 2003.

ALAN, Gülbadi, “Amerikan Board Okullarında Yürütülen Misyonerlik Faaliyetleri”, Journal of Islamic Research, 20 (4), 2007: pg. 464-475. 
, Amerikan Board'un Merzifon'daki Faaliyetleri ve Anadolu Koleji, Ankara: TTK, 2008.

Osmanlı Imparatorluğu'nda Amerikan Protestan Okulları, Ankara: TTK, 2015.

AYDIN, Mithat, "Amerikan Protestan Misyonerlerinin Ermeniler Arasındaki Faaliyetleri ve Bunun Osmanl-Amerikan İlişkilerine Etkisi”, OTAM, 19 (2015): pg.79-122.

BARNUM, Herman N., "Forty Years in Harpoot, Eastern Turkey", The Missionary Herald, 95(10), October 1899, pg. 402-403.

DANACIOĞLU, Esra, “Osmanlı İmparatorluğu’nda Amerikan Board Okulları ve Ermeniler”, Dokuz Eylül Üniversitesi Atatürk İlkeleri ve Inkılap Tarihi Enstitüsü Dergisi, 3/9-10, 1999-2000, pg. 131-144.

DEMIR, Cenk, "Amerikan Board Belgelerine Göre Talas Amerikan Kız ve Erkek Kolejleri”, Turkish Studies, Vol. 7/4, Fall 2012, pg.1405-1420.

DİNGEÇ, Emine, "Amerikan Misyoner Okullarının Ermeni Ayrllıkçı Hareketindeki Etkileri Üzerine Bir Değerlendirme", Yeni Türkiye, 60, 2014, pg. 1-10.

GÜRÜN, Kamuran, Ermeni Dosyast, Ankara: TTK, 1983.

Hamlin, Cyrus, My Life and Times, Boston: The Pilgrim Press, 1893.

HÜLAGÜ, Metin, "Osmanlı'dan Cumhuriyet'e Misyoner, Ermeni, Terör ve Amerika Dörtgeninde Türkiye", Erciyes Üniversitesi Sosyal Bilimler Enstitü Dergisi, 10, 2001, pg.57-94.

KILIÇ, Orhan, "Kendi Yazdıkları Işı̆̆ında Amerikan Misyonerlerin Harput'taki Faaliyetleri", Journal of Islamic Research, 20(4), 2007, pg.476-491.

KOCABAŞOĞLU, Uygur, Kendi Belgeleriyle Anadolu'daki Amerika, İstanbul:Arda Yayınevi, 1989.

MELCON, M. A. "The Growth and Influence and Needs of Euphrates", The Missionary Herald, Vol.99, No. 1, January 1903, Boston 1903, pg.13-15.

ÖZTÜRK, Ayhan, “Amerikan Board'un Kuruluşu ve Teşkilatlanması ve Osmanlı Devletinde Kurduğu Misyonlar", Erciyes Üniversitesi Sosyal Bilimler Enstitü Dergisi, 2/23, 2007, pg.63-74.

POLVAN, Nurettin, Türkiye'de Yabancı Öğretim, Vol. I, İstanbul: MEB Yayınları, 1952.

SEZER, Ayten,"Osmanlı'dan Cumhuriyet'e; Misyonerlerin Türkiye'deki Eğitim ve Öğretim Faaliyetleri”, Hacettepe Üniversitesi Edebiyat Fakültesi Dergisi, October 1999, pg.169-183.

STONE, F. A., Academies for Anatolia, Boston: University of Conecticut, 1984.

SUNGUROĞLU, İshak, Harput Yollarında, Vol.1, İstanbul: Elazığ Kültür ve Tanıtma Vakfı Yayınları, 1959.

ŞİMŞİR, Bilal, "Ermeni Propagandasının Amerika Boyutu Üzerine", Tarih Boyunca Türklerin Ermeni Toplumu Ille İlişkileri Sempozyumu, October 8-12, 1984, Ankara 1985, pg. 79-124.

TOZER, Henry Fanshawe, Turkish Armenia and Eastern Asia Minor, London 1881. 
TOZLU, Necmettin, “Osmanlı Devleti'nde Ermeni Eğitim Kurumları ve Faaliyetleri”, Yeni Türkiye, 60, 2014: pg.1-17.

WASBURN, George, Fifty Years in Constantinapole, Boston: Riverside Press, 1909.

WHEELER, Crosby H., "For Young People-Euphrates College, Harpoot, Turkey" The Missionary Herald, 84/3, March 1888: pg.137-138. 